\title{
Exploration, collection and conservation of multicrop germplasm from Kishtwar district of Jammu and Kashmir, India
}

\author{
Sheikh M. Sultan* \\ ICAR-National Bureau of Plant Genetic Resources (ICAR-NBPGR), Regional Station \\ Srinagar -191132 (Jammu and Kashmir), India \\ Narender Negi \\ ICAR-National Bureau of Plant Genetic Resources (ICAR-NBPGR), Regional Station \\ Shimla -171004 (Himachal Pradesh), India \\ Susheel Kumar Raina \\ ICAR-National Bureau of Plant Genetic Resources (ICAR-NBPGR), Regional Station \\ Srinagar -191132 (Jammu and Kashmir), India \\ *Corresponding author. E-mail: sheikhmsultan@gmail.com

\begin{abstract}
Systematic exploration and germplasm collection trips were conducted across Kishtwar district of Jammu and Kashmir state covering Chatroo valley, Padder valley and Kishtwar main including areas of Dachan, Surror, Sarthal, Bhonjwa and Drabshala during 2013, 2015 and 2018. A total of 113 germplasm accessions belonging to 29 species of crops and wild relatives from as many as 40 collection sites were collected at altitudes ranging from 1340-2670 m. Several areas in Sarthal, Bhonjwa, Dachan and Gulabgarh Padder were first time explored. Crop group wise accessions collected are pulses (39) mostly common beans, cereals (30) mostly maize, vegetables and spices (25), pseudocereals and millets (16), besides one accession each of Glycine max, Solanum pseudocapsicum and Nicotiana tabacum. The germplasm has been conserved in National Gene Bank (NGB), New Delhi. This study highlights information on the germplasm collected/observed and threats leading to biodiversity loss/genetic erosion in the highly fragile region of Kishtwar.
\end{abstract} \\ Abstract
}

Keywords: Conservation, Exploration, Germplasm collection, Kishtwar, Plant genetic resources

\section{INTRODUCTION}

Kishtwar, popularly known as the "Land of Sapphire and Saffron" is an extremely mountainous region with very steep slopes having total forest area of 58394 hectares rich in forest products. Vegetation and climate in the area can broadly be categorized into sub-tropical, temperate and alpine with wide diversity of fauna and flora. This valuable biodiversity however is being increasingly threatened nowadays. In general, biodiversity in the Himalayas including its distribution and survival has been adversely affected by climate change and increased anthropogenic pressure (Shrestha et al., 2012, Yue et al., 2013). The diversity of several important crops including cereals, pseudocereals, millets, pulses etc. likewise, is threatened by rapid urbanization and habitat erosion as well as unpredictable and extreme climatic events including increasing frequency of drought, rising temperatures and flooding. Crop diversity in farmer's field is diminishing fast and the wild relatives or 'wild cousins' of our food crops continue to

\section{Article Info}

DOI: 10.31018/jans.v11i2.2070

Received: April 19, 2019

Revised: May 18, 2019

Accepted: May 25, 2019

\section{How to Cite}

Sultan, S.M. et al. (2019).

Exploration, collection and conservation of multicrop germplasm from Kishtwar district of Jammu and Kashmir, India. Journal of Applied and Natural Science, 11(2): 398 - 403 https://doi.org/10.31018/ jans.v11i2.2070 
the region is a much better option to safeguard diversity at risk. The present study reports on collection expeditions carried out in the years 2013, 2015 and 2018 in different areas of Kishtwar primarily to capture crop genetic variability and conserve the representative germplasm in National Gene Bank for future use.

\section{MATERIALS AND METHODS}

Description of the study area: Kishtwar in Jammu province of north western Indian Himalayan state of Jammu and Kashmir lies at $32^{\circ} 53^{\prime}$ and $34^{\circ} 21^{\prime} \mathrm{N}$ latitude and $75^{\circ} 1^{\prime}$ and $76^{\circ} 47^{\prime} \mathrm{E}$ longitude with an average altitude of $1638 \mathrm{~m}$ is the third least populous district after Kargil and Leh having a total geographical area of 1,644 sq km. The district is flanked by lofty Himalayas (Pir Panjal range) from all sides and the entire tract is extremely mountainous, bearing very steep slopes pierced by deep valleys like Marwah-Wadwan valley, Padder valley and Chatroo valley. The area is practically devoid of any flat ground except Kishtwar plateau and Atholi plateau in Padder valley and is bounded by Kargil district in the North, Northeast and East, Himachal Pradesh in the South and Anantnag, Ramban and Doda districts in the West (Fig. 1). River Chenab is the major river of the district. Famous Synthan pass $(3,784 \mathrm{~m})$ links Anantnag with Kishtwar. Kishtwar High Altitude National Park situated in the North of Kishtwar between $33^{\circ} 20^{\prime}-34^{\circ} 40^{\prime}$ North latitude and $75^{\circ} 40^{\prime}-76^{\circ} 10^{\prime}$ East longitudes is spread over an area of $425 \mathrm{sq}$. kms harboring 35 villages. The area being rural in nature has agriculture based economy. Agriculture is the main source of livelihood in the district as in the rest of the state. It is mostly a mono cropped zone with low production and productivity. Suitable hill sides are cultivated after having them terraced into fields. The major crops grown in the district are maize, paddy, wheat, barley, pulses particularly common beans and vegetables. The main fresh fruit produced in the district includes apple, apricot, plum, pear and peach and dry fruits produced include mostly walnuts. Saffron is also grown at some places. Soil is spodosolic, undulating and prone to erosion. The monsoon hardly reaches here and it is due to low average annual precipitation (36.04 inches/year) that the area has been declared drought prone consequently making it insufficient in food grain production; particularly the MarwahWardwan area which remains cut off for 5-6 months in a year due to snowfall in winter.

Germplasm collection: During the years 2013, 2015 and 2018, systematic expeditions were conducted across Kishtwar district covering Chatroo valley, Padder valley and Kishtwar main including areas of Dachan, Surror, Sarthal, Bhonjwa and Drabshala. Prior to that information on region's flora, agriculture and results from previous collect-

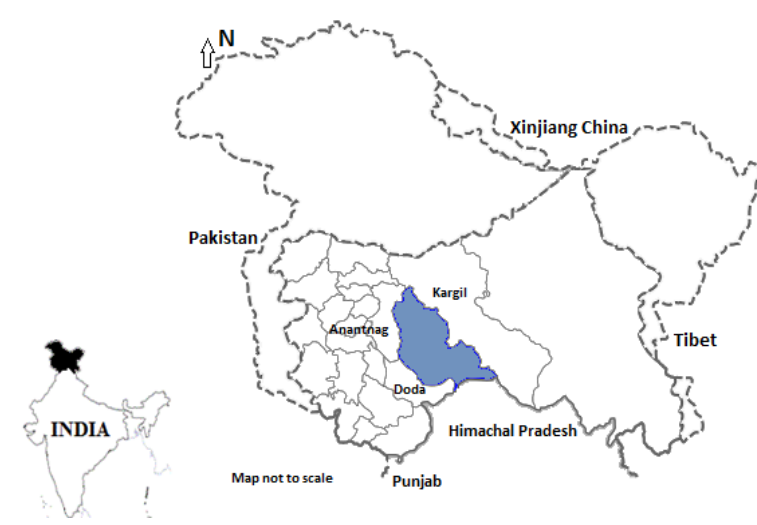

Fig. 1. Map of Jammu \& Kashmir state of India. The study area of Kishtwar district is marked in color.

ing missions were gathered and analyzed with the specific aim of better planning of these explorations. The main sources of germplasm samples of cultivated crops were farmer's fields or the threshing yards/farm stores in case the crop had already been harvested. In general, random sampling was followed for field collection and farm stored material whereas small samples were bulked in case of wild species. In a few cases samples were also collected from seed sellers, which made it possible to find out and collect old traditional material. The germplasm of wild species was collected from roadsides, on the sides of farmer's fields and from rock crevices. At each collecting site a passport data sheet was filled in as per standard format (Moss and Guarino, 1995) using data from a hand -held GPS system that included latitude, longitude and altitude of the place of collection. Data were collected through informed consent semistructured interviews and questionnaires on technical information from each person from whom germplasm samples were collected in the areas surveyed. Each collection was assigned a unique collector number. The collected material was deposited in the NGB (National Gene Bank) for long term conservation.

\section{RESULTS AND DISCUSSION}

A total of 113 germplasm accessions belonging to 29 species of crops and wild relatives from as many as 40 collection sites across Kishtwar situated between $33^{\circ} 07^{\prime}-33^{\circ} 34^{\prime} \mathrm{N}$ latitude and $75^{\circ} 33^{\prime}$ $76^{\circ} 11^{\prime} \mathrm{E}$ longitude at an altitude ranging from 1340-2670 m were collected during exploration and germplasm collection programmes in 2013, 2015 and 2018 (Table 1). Following are the crop group wise germplasm collections:

Cereals: Maize is the most common cereal crop cultivated throughout Kishtwar and a key source of food, fodder and livelihood of people. The crop is generally grown under rainfed conditions either singly or intercropped with pulses particularly common beans. Traditional varieties/landraces of 
Table 1. Plant Genetic Resources collected from Kishtwar district of Jammu \& Kashmir, India.

\begin{tabular}{|c|c|c|c|c|}
\hline S.N. & $\begin{array}{l}\text { Crop species (No. of } \\
\text { collections) }\end{array}$ & $\begin{array}{l}\text { Common } \\
\text { name }\end{array}$ & $\begin{array}{l}\text { Local } \\
\text { name }\end{array}$ & Collection sites \\
\hline 1 & $\begin{array}{l}\text { Phaseolus vulgaris } \\
\text { (31) }\end{array}$ & French bean & Rajma & $\begin{array}{l}\text { Drabshala Surror, Salana, Kankoot Surror, } \\
\text { Dhara Surror, Angara Sarthal, Galigadh Sar- } \\
\text { thal, Gorna Sarthal, Bidha, Thakraie, Massu } \\
\text { Padder, Narhal Padder, Galhar Naghseni, } \\
\text { Danghdooro Dachan, Pinjradi, Naghni } \\
\text { Bhonjwa, Marmulla Chatroo, Bamalpora } \\
\text { Gurinal Chatroo, Sigdi Bata }\end{array}$ \\
\hline 2 & Vigna radiata $(01)$ & Green gram & Moong & Chingam Chatroo \\
\hline 3 & Vigna mungo (03) & Black Gram & Mash & Salana Drabshala, Pochal \\
\hline 4 & Vigna unguiculata (01) & Cowpea & Rongi & Gorna Sarthal \\
\hline 5 & Lens culinaris (02) & Lentil & Masur & Gorna Sarthal, Pochal \\
\hline 6 & $\begin{array}{l}\text { Macrotyloma uniflorum } \\
\text { (01) }\end{array}$ & Horse Gram & Kulth & Gorna Sarthal \\
\hline 7 & $\begin{array}{l}\text { Coriandrum sativum } \\
\text { (06) }\end{array}$ & Coriander & $\begin{array}{l}\text { Dhaniwal/ } \\
\text { Dhania }\end{array}$ & $\begin{array}{l}\text { Passerkoot Chatroo, Padyarana Naghsani, } \\
\text { Karthaie Padder, Bhandera, Thathri, Prem } \\
\text { Nagar }\end{array}$ \\
\hline 8 & $\begin{array}{l}\text { Trigonella } \\
\text { graecum (03) }\end{array}$ & Fenugreek & Meethi & Chingam Chatroo, Bhandera, Gorna Sarthal \\
\hline 9 & Bunium persicum (02) & Black cumin & Zeera & Karthaie Padder \\
\hline 10 & $\begin{array}{l}\text { Elymus semicostatus } \\
(06)\end{array}$ & Wildrye & & $\begin{array}{l}\text { Synthan Maidan, Watsir Chingam, Narian, } \\
\text { Lower Naghni, Lower Galhar Naghsani, Low- } \\
\text { er Bumalpora Gurinal Chatroo }\end{array}$ \\
\hline 11 & $\begin{array}{l}\text { Fagopyrum dibotrys } \\
(02)\end{array}$ & $\begin{array}{l}\text { Wild Buck- } \\
\text { wheat }\end{array}$ & $\begin{array}{l}\text { Dhrav/ } \\
\text { Mukti }\end{array}$ & Galigadh Sarthal, Naghni Bhonjwa \\
\hline 12 & $\begin{array}{l}\text { Fagopyrum ecsulentum } \\
(02)\end{array}$ & Buckwheat & & Narhal Padder, Galhar Naghseni \\
\hline 13 & Zea mays (15) & Maize & $\begin{array}{l}\text { Kukdi/ } \\
\text { Maka }\end{array}$ & $\begin{array}{l}\text { Bidha, Galigadh Sarthal, Gorna Sarthal, } \\
\text { Aghral Devi Mandir Sarthal, Ikhala, Naghni } \\
\text { Bhonjwa, Salana Drabshalla, Massu Padder, } \\
\text { Kundal Padder, Marmulla Chatroo, Bumal- } \\
\text { pora Gurinal Chatroo }\end{array}$ \\
\hline 14 & $\begin{array}{l}\text { Lycopersicon esculen- } \\
\text { tum (03) }\end{array}$ & Tomato & Tamatar & $\begin{array}{l}\text { Galigadh Sarthal, Naghni Bhonjwa, Massu } \\
\text { Padder }\end{array}$ \\
\hline 15 & Cucumis sativus $(03)$ & Cucumber & Kheera & $\begin{array}{l}\text { Gorna Sarthal, Massu Padder, Marmulla } \\
\text { Chatroo }\end{array}$ \\
\hline 16 & Capsicum annum (03) & Chilli & Mirch & $\begin{array}{l}\text { Gorna Sarthal, Naghni Bhonjwa, Massu Pad- } \\
\text { der }\end{array}$ \\
\hline 17 & Hordeum vulgare (04) & Barley & Jau/Grim & Aghral Devi Mandir Sarthal, Danghdooro \\
\hline & & & & $\begin{array}{l}\text { Dachan, Salana Drabshalla, Galhar } \\
\text { Naghsani }\end{array}$ \\
\hline 18 & Cucurbita pepo (02) & Pumpkin & & Aghral Devi Mandir Sarthal, Naghni Bhonjwa \\
\hline 19 & $\begin{array}{l}\text { Chenopodium album } \\
\text { (03) }\end{array}$ & Chenopod & $\begin{array}{l}\text { Ba- } \\
\text { jarbangh }\end{array}$ & $\begin{array}{l}\text { Aghral Devi Mandir Sarthal, Massu Padder, } \\
\text { Narhal Padder }\end{array}$ \\
\hline 20 & $\begin{array}{l}\text { Amaranthus hypochon- } \\
\text { driacus (03) }\end{array}$ & Amaranth & $\begin{array}{l}\text { Ganharl } \\
\text { Babri }\end{array}$ & Aghral Devi Mandir Sarthal, Narhal Padder \\
\hline 21 & Glycine max (01) & Soybean & & Lower Aghral Devi Mandir Sarthal \\
\hline 21 & $\begin{array}{l}\text { Solanum pseudocapsi- } \\
\text { cum (01) }\end{array}$ & $\begin{array}{l}\text { Jerusalem } \\
\text { Cherry }\end{array}$ & Amluk & Shalimar \\
\hline 23 & Oryza sativa (05) & Paddy & $\begin{array}{l}\text { Dhan/Lal } \\
\text { Dhan }\end{array}$ & $\begin{array}{l}\text { Ikhala, Naghni Bhonjwa, Massu Padder, } \\
\text { Bumalpora Gurinal Chatroo }\end{array}$ \\
\hline 24 & Nicotiana tabacum (01) & Tobacco & $\begin{array}{l}\text { Desi } \\
\text { tamakoo }\end{array}$ & Naghni Bhonjwa \\
\hline 25 & Eleusine coracana (03) & Finger millet & $\begin{array}{l}\text { Mandua/ } \\
\text { Kudroo }\end{array}$ & Bidha, Karthaie Padder, Massu Padder \\
\hline 26 & Setaria italica (01) & Foxtail millet & Sallan & Massu Padder \\
\hline 27 & $\begin{array}{l}\text { Panicum miliaceum } \\
\text { (01) }\end{array}$ & Proso millet & Cheena & Narhal Padder \\
\hline 28 & Setaria viridis $(01)$ & & & Marmulla Chatroo \\
\hline 29 & Allium sativum (03) & Garlic & Lahsun & Karthaie Padder, Thathri, Prem Nagar \\
\hline
\end{tabular}


maize are still popular in the farmer's fields throughout the state owing to their better grain quality in terms of taste, better fodder quality, wider adaptability to local conditions, resistance to draught, cold, insects and pests, early maturity and low input requirement. 15 diverse accessions of this crop have been collected during the course of present study from various parts of Kishtwar often with smaller cobs showing variations in grain size and color of yellow, orange or white. White maize has been found to be more common in this region of the state. In an earlier study we have reported protein content of $13.6 \%$ and $15.2 \%$ in two maize genotypes collected from Kishtwar with corresponding oil content of $3.47 \%$ and $4.02 \%$ respectively (Sultan et al., 2018). Maize thus seems to be an important source of nutrition for local people. In the north western Indian Himalayan state Jammu and Kashmir, maize is second most important crop after rice and is a staple food of tribal population (Najeeb et al., 2012). At many places in Kishtwar maize and paddy are cultivated side by side in characteristic terraced fields (Fig. 2) but cultivation of paddy is less common than that of maize. Five accessions of paddy including famous red rice landrace 'Lal Dhan' have been collected. This awned landrace was found to be cultivated by a single farmer in Massu village of Padder. Red rice awned landrace locally known as 'Zag' has also been collected from a field at Bumalpora Gurinal in Chatroo. Four accessions of another cereal Hordeum vulgare cultivated occasionally in some areas of Kishtwar were also collected. Unlike naked barley cultivation and consumption in Ladakh province of the state, the barley cultivated in Kishtwar hills is always hulled and is frequently used by local people during religious ceremonies. We have not been able to collect wheat from Chatroo valley, Padder valley and Kishtwar main including areas of Dachan, Surror, Sarthal, Bhonjwa and Drabshala during the course of our present study.

Pseudocereals: Two accessions each of Fagopyrum esculentum and Fagopyrum dibotrys and three accessions each of Chenopodium album and Amaranthus hypochondriacus were collected during the course of present study. Fagopyrum dibotrys grows wild on slopes, as a weed in maize fields or in kitchen gardens at many places especially in Padder and Sarthal areas (Fig. 2). According to local people its young tender leaves are sometimes used as a vegetable having sour taste. Chenopodium album has first time been seen by authors to be cultivated in the state of Jammu and Kashmir. Out of three accessions, one was collected from farmer's field and second from farmer store in Padder area whereas third one has been collected from wild growing in a maize field in Sarthal area. Three accessions of Amaranthus hypochondriacus have been collected from maize fields in Sarthal and Padder areas. The amaranth having red colored inflorescences was found to be grown on maize field bunds whereas one accession with greenish inflorescence has been collected from within the field.

Millets: Minor millets found to be cultivated in Kishtwar especially in Padder valley Eleusine coracana, Setaria italica and Panicum miliaceum. Three accessions of Eleusine coracana which seems to be cultivated more commonly compared to other two millets were collected. One accession of a primitive type of Setaria italica cultivated on a small patch of land by a single farmer in Massu padder (Fig. 2) was also collected. Locally called as 'Sallan' according to the farmer is tasty when consumed as 'sattu' after roasting. One accession of Panicum miliaceum, the third minor millet was collected which among the three is rarely cultivated in the region. Farmers are increasingly losing interest in these crops now and according to locals there cultivation has now drastically declined. In Ladakh, Setaria italica is more commonly cultivated than Eleusine coracana and that during last few decades, the cultivation there also has significantly declined (Sultan and Omvir, 2013). One accession of Setaria viridis, the wild cousin of Setaria italica was also collected from the area.

Grain legumes: Common bean (Phaseolus vulgaris) is the important and most common grain legume cultivated in the entire area mostly intercropped with maize and we have collected 31 diverse accessions from different areas. Variability was collected in seed size, shape and color. In the state of Jammu and Kashmir, common beans are often named according to the area of their production for example, famous Shopian rajma, Gurez rajma, Badherwah rajma, Kishtwar rajma, Poonch rajma etc. Same trend is followed within Kishtwar district also with Warwan rajma, Dachan rajma, Padder rajma, Keshwan rajma etc. named after the respective areas of their production within the district. Of particular interest is our collection of 'Keshwan rajma' produced in and around rough hilly terrains of Keshwan area. This short duration genotype with brownish cuboid seeds has an average seed length, seed width and 100-seed weight of $12.5 \mathrm{~mm}, 8.0 \mathrm{~mm}$ and $36.8 \mathrm{~g}$ respectively (Sultan et al., 2014) and is believed to be very tasty by locals. Besides common beans other grain legume germplasm collected from the area include Vigna unguiculata, Vigna radiata, Vigna mungo, Lens culinaris and Macrotyloma uniflorum. These pulses are cultivated occasionally but not as frequently as common beans. One accession of another grain legume soybean (Glycine max) was also collected from Farmer's field. Limited numbers of heavy pod bearing plants were characteristically grown at the rim of a field near village Aghral Devi Mandir Sarthal.

Vegetables and spices: Good quantities of differ- 
Sultan, S.M. et al. / J. Appl. \& Nat. Sci. 11(2): 398 - 403 (2019)

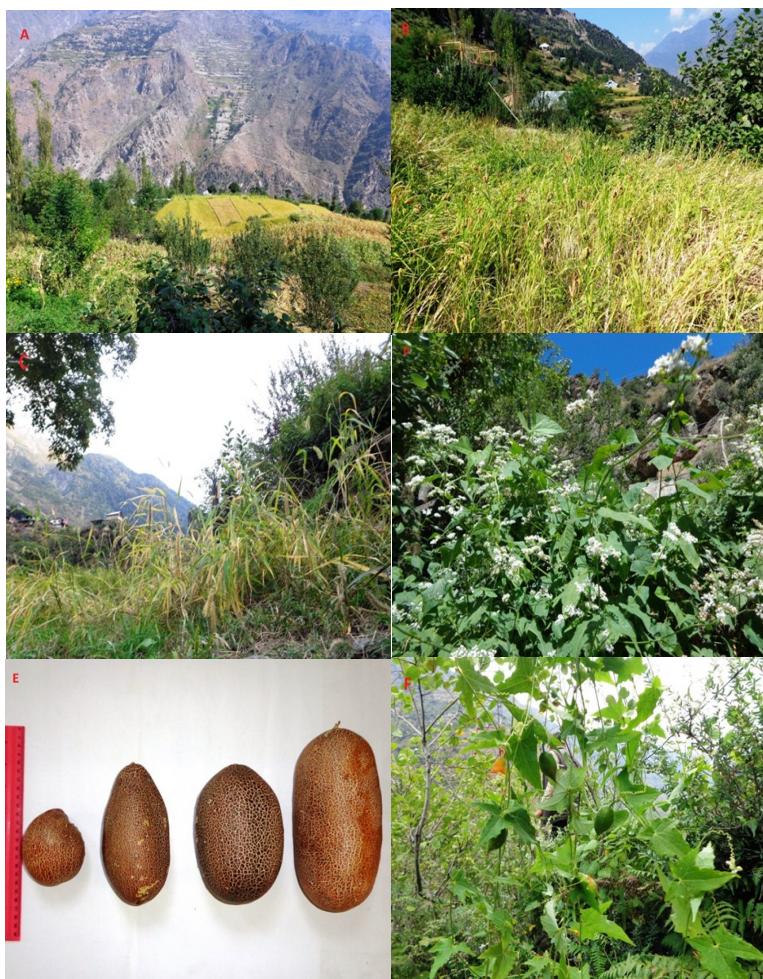

Fig. 2. From top left to right: $\boldsymbol{A}$ - Characteristic terraced fields in hill district of Kishtwar (Jammu \& Kashmir) with mixed farming of maize, paddy and pulses; $\boldsymbol{B}$ - a field of Finger millet (Eleusine coracana) in Bidha; $\boldsymbol{C}$ - a small field of primitive type of Foxtail millet (Setaria italica) locally called as 'Sallan' in Massu Padder; D - buckwheat species, Fagopyrum dibotrys growing wild along roadside in Sarthal area; E - local cucumber collected from Gorna in Sarthal area and $\boldsymbol{F}$ - edible creeping cucumber (Solena heterophylla) growing wild in Nagni area of Bhonjwa Kishtwar.

ent kinds of vegetables are produced in Kishtwar especially in Sarthal area. Inspire of introduction of high yielding varieties of vegetables in the district, traditional landraces are still very popular owing to their good taste. During the present study three (03) accessions each of Lycopersicon esculentum, Cucumis sativus, Trigonella foenumgraecum, Allium sativum and Capsicum annum have been collected mostly from Sarthal areas. Six (06) accessions of Coriandrum sativum and two (02) each of Cucurbita pepo and Bunium persicum were also collected. Good variability has been collected in Coriandrum sativum, the seeds vary greatly in shape, size and aroma. The two accessions of Bunium persicum have been collected from Padder area where it grows wild on hill slopes. Locally called as 'Zoor' or 'Kala zeera', its seeds are used as spice and condiment. It is collected by the local people and sold in the market thus, playing an important role in income generation for most of the families. However, over last few years there has been a drastic decline in its production and this valuable plant genetic re- source is now highly endangered. Overharvesting over the years may be one of the main reasons for its decreasing populations.

Other crops: One accession each of Nicotiana tabacum and Solanum pseudocapsicum have also been collected during the study. Nicotiana tabacum has been collected from Naghni Bhonjwa where it was found growing as a roadside weed. According to locals this 'Desi tamakoo' was cultivated in the past for domestic use and now its cultivation has been almost stopped. Solanum pseudocapsicum was collected from roadside near Shalimar area where few unusually quite bigger plants of about 4 - 6 feet tall with heavy fruit bearing were seen growing. Otherwise smaller plants of this wild Solanum can be seen growing on hill slopes at several places in the area. Locally called as 'Amluk', its ripe berries in past were used as 'Chutney' by many people. However, due to its intense and sharp smell it has not been so popular as revealed by many locals.

The main source of livelihood of the people of Kishtwar is agriculture as around $90 \%$ of the population is rural and directly or indirectly involved with the agriculture and allied sectors. A total of 25872 hectares area of the District is under food and non food crops out of which about half of the area is under high yielding varieties of different crops (DS\&EO, 2017). Further, a total of 8889 hectare area is under major horticulture crops which comprise 4227 hectares under fresh fruits and 4662 hectares under dry fruits. The main fresh fruit produced in the district includes apple, apricot, plum par and peach and dry fruits produced chiefly include walnut and almond. Saffron is also cultivated at few places in the district on an area of roughly 120 hectares.

The forests are mostly comprised of deodar, fir and pine trees. Entire area is very rich in a range of medicinal plants and some wild fruits. Wild edible plants of Allium roylei, Bunium persicum, Corylus jacquemontii, Crataegus songarica, Elaegnus umbellata, Ficus palmata, Morus serrata, Pinus gerardiana, Prunus armeniaca, Prunus cornuta, Punica granatum, Pyrus paschia, Rubus sp., Viburnum grandiflorum, Zizyphus oxyphylla etc. can be seen growing at different places. During the course of present study we have noted wild edible creeping cucumber species namely Solena heterophylla growing abundantly in Nagni area of Bhonjwa Kishtwar (Fig. 2). The locals especially children fondly eat its ripe reddish fruits. Good populations of Perilla frutescence growing along roadside have also been seen by the authors growing in the area. Unfortunately this valuable biodiversity including that in agricultural fields is increasingly been threatened nowadays. Construction of network of roads has lead to habitat loss. Inaccessible pockets in the district known for 
cultivation of countless landraces are being connected by the roads and high yielding varieties are fast spreading replacing traditional varieties. With the introduction of exotic seeds and plants, alien species of weeds and pests are making their way into this once untouched neat and clean hilly area with serene environment. We have seen several populations of alien species of Xanthium spinosum around agricultural fields in Gulabgarh area of Padder valley. Such invasive alien species pose a significant threat to the biodiversity in general and in agricultural fields. Species which are listed to be of immediate cause of concern in the Kishtwar district include Parthenium hysterophorus, Xanthium spinosum, Cirsium arvense, Anthemis cotula (Bhutyal et al., 2014). Half a dozen hydroelectric power projects are functioning in the district and many more are coming up. Several villages have been dislocated and prime agricultural land has been inundated. The collection and conservation of available plant genetic resources from the region thus becomes inevitable.

\section{Conclusion}

The collected 113 multicrop germplasm accessions belonging to 29 species of crops and wild relatives from as many as 40 collection sites across Kishtwar have been conserved at National Gene Bank (NGB), ICAR-NBPGR New Delhi under long term conservation. Genetic diversity forms the core of initial material for the improvement of the characteristics of crops either by farmers, plant breeders or molecular methods. Genetic resources support the maintenance of biological diversity, promote sustainable agricultural production and contribute to the sustainable development and diversification of agricultural production. The plant genetic diversity allows crops and varieties to adapt to ever changing conditions and to overcome the constraints caused by biotic and abiotic stresses. In future, with the help of advanced molecular biological methods, it will be possible to detect in the conserved material the values unknown so far, which can be used for the breeding of new disease resistant or otherwise value added varieties.

\section{ACKNOWLEDGEMENTS}

Authors place on record their sincere thanks to Director, ICAR-NBPGR, New Delhi for providing facilities and support during explorations trips. The authors are grateful to the authorities of various Govt. /Non Govt. organizations in the area for their full cooperation during our study.

\section{REFERENCES}

1. Bhutyal, Ruchika and Sanjay, B. (2014). Invasive alien plants of Kishtwar district (North West) Himalayas, Jammu and Kashmir, India. Journal of Global Biosciences 3(3): 651-659.

2. DS and EO (2017). District Statistical Handbook. Kishtwar 2016-17, Published by District Statistical \& Evaluation Officer, Directorate of Economics \& Statistics, Govt. of Jammu \& Kashmir.

3. Moss, H. and Guarino, L. (1995). Gathering and recording data in the field. In: L. Guarino, V. Ramanatha Rao and R. Reid (eds) Collecting Plant Genetic Diversity: Technical Guidelines. CABI International, United Kingdom, pp 367-417.

4. Najeeb, S., Rather, A. G., Zarger, M. A., Ahangar, M A., Sheikh, F. A., Parray, G. A., Bhat, Z. A., Sofi, P. A., Kashap, S. C., Ishfaq, A., Dar, Z. A., Mehfoza, H. and Bardi, Z. A. (2012). Maize landraces of Kashmir: pre-sent status and future prospects. Maize Genetics Coop-eration Newsletter, 86: 1-11.

5. Shrestha, U. B., Gautam, S. and Bawa, K. S. (2012). Widespread climate change in the Himalayas and associated changes in local ecosystems. PLoS ONE 7:e36741. https://doi.org/10.1371/journal.pone. 0036 741

6. Sultan, S. M., Dar, S. A., Dand, S. A. and Sivaraj, N. (2014). Diversity of common bean in Jammu and Kashmir, India: a DIVA- geographic information system and cluster analysis. Journal of Applied and Natural Scienc, e 6 (1): 226-233.

7. Sultan, S. M., Dikshit, N., Mohanty, C. S., Rout, P. K. and Raina, S. K. (2018). Biochemical evaluation of dent corn (Zea mays L.) genotypes cultivated under rainfed conditions in the hills of north western Indian Himalayan state of Jammu and Kashmir. Journal of Applied and Natural Science 10(1): 196 - 201.

8. Sultan, S. M. and Omvir Singh (2013). Peudocereals and millets - the lost crops of Kashmir. Genetic Resources and Crop Evolution 60(3): 1191-1199.

9. Yue, T., Zhao, N., Ramsey, R. D., Wang, C., Fan, Z., Chen, C., Lu, Y. and Li, B. (2013). Climate change trend in China, with improved accuracy. Climate Change 120:137-151. 